\title{
Self-Concept, Interest in Becoming a TeACHer, Prerequisite COURSES: What do THE MOST DETERMINANT FACTORS IN Microteaching Competencies of Prospective Teachers?
}

\author{
Tomo Djudin \\ Physics Education Department of Education and Teacher Training Faculty, Tanjungpura University, Pontianak, \\ West Kalimantan, Indonesia \\ E-mail: tomo.djudin@yahoo.com
}

\begin{abstract}
Self-concept, interest, learning motivation, and prerequisite knowledge potentially contributes to academic achievement. The aim of this study was to determine the relationship between self-concept, interest in becoming a teacher, academic achievement of prerequisite courses and prospective teachers' competencies of microteaching. This correlational study involved 105 sixth semester students of science department in Education and Teacher Training Faculty (FKIP) of Pontianak, Tanjungpura University. The data collected by using the self- concept questionnaire and the questionnaire of interest in becoming a teacher. The achievement of prerequisite courses and the students' competencies of microteaching taken from the academic subdivision of the faculty. The analysis found that self-concept, interest in becoming a teacher, and academic achievement in prerequisite courses associate significantly with prospective teachers' competencies of microteaching (respectively $r_{s}=.35, r_{s}=.38$, and $r_{\mathrm{s}}=.60, p<.05$ ). In addition, coefficient of multiple correlation is also significant $(R=.61, \mathrm{p}<.05)$. It means that the relative contribution of predictor variables of this study on prospective teachers' competencies of microteaching is $37.60 \%$ and the remaining $62.40 \%$ is determined by other uninvestigated variables. The study indicated that the prerequisite courses relate significantly with students' ability to execute microteaching. Thus, an institution of teacher training should continually upgrade the quality of learning and instruction by providing the essential prerequisite content of courses the prospective teachers required.
\end{abstract}

Keywords: Self-Concept; Prerequisite Courses; Interest in Becoming a Teacher; Microteaching Competency

\section{INTRODUCTION}

Generally, a person has a self-concept of a profession or job. Self-concept is what a person believes about himself, or a map that each person consults in order to understand himself, especially during moments of crisis or situations in which he makes a choice. The self-concept is a fundamental internal standard or criterion of personality that, as a referent function, regulates and directs the behaviour and activities of the individual (Musek as cited Zlatkovic et al., 2012). According to Slameto (2010), self-concept is a mental picture of oneself which consists of knowledge about oneself, self-expectations and self-assessment. Individuals who have a positive self-concept will be self-confidence, able to recognize his/her strengths and weaknesses, able to solve problems and evaluate themselves and realize that everyone has feelings, desires and behaviours that are not entirely accepted by society (Brook and Emmert as cited in Ningrum et al., 2013). Simply stated, self-concept could influence students' interests and motivation for learning. Unfortunately, self-concept is rarely seen as a remarkable factor of teacher's professional activities (Zlatkovic et al., 2012), although it is highly associated with both internal and external factors of effective teaching. The emergence of individual's interest in an object is characterized by the emergence of a desire to be directly involved and feel interested or happy about an object (Hidayat, 2008; Hurlock, 2010).

According to Djaali (2011), interest is influenced by many factors, including work, socio-economic status, talent, age, gender, personality, and environment. The interest contains elements: cognition, emotion. Therefore, interest is considered a conscious response. If not aware, interest will have no meaning for someone. The students who have an interest in the teaching profession will have an awareness that the teaching profession is important for him. The interest in becoming a teacher is an interest in the teaching profession so that it will take time, energy thought and even money to fulfil or realize his dream of becoming a teacher. 
Teacher's profession is a profession that requires someone to have professional teacher competencies including pedagogical competence, personality competence, social competence, and professional competence (Mulyasa, 2006; Umura, 2015).

To prepare students to become professional teachers, the sixth-semester students as perspectives teachers have to enrol the microteaching and the real experience practice (PPL) course in the seventh semester that generally to be a curriculum of the teacher training institution of higher education (LPTK) in Indonesia. Simply stated, microteaching and PPL courses are an integral part of the process of preparing professional teacher candidates. There are several pedagogical competency courses before enrolling microteaching must be taken by students in LPTK, they are; teaching and learning strategy, instructional media, curriculum analysis, teaching-learning evaluation, and instructional design. These prerequisite courses are essential in the LPTK curriculum.

Microteaching can be assumed as a way of training skills or teaching practices in a small or limited scope. Microteaching learning is an initial training in cultivating the competencies and teaching skills through actualizing them in real class (Asril, 2011). Microteaching is also a means to dare to appear in the face of the atmosphere in the classroom, controlling emotions, speech rhythms and others. Through microteaching, it is expected that prospective teachers or students are not awkward and embarrassed in facing students in the real class. The students can prepare themselves regarding making a lesson plan, sequencing content subject matter, teaching-learning method, instructional media, and evaluation instrument they employed in teaching practice. In addition, there are eight components of basic teaching skills trained in microteaching, they are; skills opening and closing lessons, explanation skills, skills in making variations, skills in providing reinforcement, skills in asking questions, skill in managing class, teaching skills for individuals or small groups; skill in guiding small group discussions (UPT Pembelajaran, 2018).

Several previous studies regarding self-concept, learning motivation, interest, and student interest in becoming a teacher had been conducted to investigate their impacts on the students' achievement. The results concluded that selfconcept in learning had a positive effect on academic achievement and student learning motivation (Agustina \& Mutia, 2015; Efendi, 2013; Qalsum, Nurhayati, \& Yani, 2015; Sistiani, 2009). Dwija (2008), for instance, concluded: (1) there is a positive and significant relationship between self-concept and sociology learning outcomes with a contribution of $18.20 \%$; (2) there is a positive and significant relationship between achievement motivation and learning outcomes with a contribution of $17.20 \%$; (3) there is a positive and significant relationship between parental attention and learning outcomes with a contribution of $31.70 \%$; (4) there is a positive and significant relationship together between self-concept, achievement motivation, parental attention and learning outcomes with a contribution of $46.30 \%$. There is a positive and significant relationship between the interest in becoming a teacher and learning achievement (Ningrum, 2013; Widadi, 2000;). Setiaji (2015) found that teaching career motivation, self-efficacy, and socio-economic status had a positive effect on academic achievement and interest in becoming a teacher.

Several studies examined the ability of students to apply the eight basic skills in microteaching lectures. They concluded that most students could display eight teaching skills with varying percentages. Furthermore, the studies concluded that the better the microteaching and PPL conducted by prospective teacher students, the better his professional competence (Ardi, 2014; Frasetyana, et al., 2015).

Until now, from tracing the previous studies, the investigations focused on examining the influence of students' achievements of prerequisite courses on the microteaching competency are far from conducted including in Pontianak, Tanjungpura University. In addition, the simultaneous relationship between self-concept, interest in becoming a teacher, prerequisites courses and microteaching competency, unfortunately, have never been investigated. Indeed, these variables play an important role in building teacher professional competence. A teacher training institution should recognize objectively the data or information related to the intensity of self-concept, interest in becoming a teacher, and pedagogical courses that can be used as a database for planning academic service improvement programs and policies.

Based on the theoretical viewpoints and the results of several previous studies as mentioned above, the main objective in this study is to determine the extent of relationship individually and simultaneously between selfconcept, interest in becoming a science teacher, academic achievement of prerequisite courses and the prospective teachers' microteaching competency in FKIP of Pontianak Tanjungpura University and assess determination indexes as well.

\section{METHODOLOGY}

To determine the relationship between self-concept, interest in becoming a teacher, and academic achievement of prerequisite courses and prospective teachers' competencies of microteaching regarding the current empirical conditions of the research context, the descriptive-correlational study was carried out in this study.

The target population is the total students of science education, Departement of Education and Teacher Training Faculty (FKIP) of Pontianak, Tanjungpura University enrolled microteaching course in the sixth-semester academic year 2018/2019 that amount of 182 students. Determination of sample size consists of 105 students by using the unproportioned stratified random sampling technique.

Data collected by administering two questionnaires, they are; self-concept questionnaire on the teaching profession and questionnaire of interest in becoming a teacher. Content and construct validity of these questionnaires consist of fitness of indicators with items, appropriateness of aspects 
covered in the questionnaire of blueprints, the clarity of redactional form including sentences (words) written has been validated by using the expert judgements. The revisions of the questionnaires performed based on expert comments and suggestions. Reliability of self-concept scales and interest in becoming a teacher scale assessed by Cronbach Alpha coefficient, respectively Alpha $=0.88$ and Alpha $=$ 0.79 were satisfactory. Students' achievement of prerequisite course of microteaching consists of teaching and learning strategy, instructional media, curriculum analysis, teachinglearning evaluation, and instructional design. The average scores of these prerequisite courses documented in the administration and academic division or instruction unit of faculty will be calculated. The prospective teacher's competency of microteaching based on the score or grade assessed by the lecturers as a supervisor using a uniform observation format of microteaching practice.

The coefficient of correlations between self-concept, interest in becoming a teacher, the academic achievement of prerequisite courses and prospective teachers' competencies of microteaching were analysed by using Rank Spearman Rho and Multiple Correlation. The determination indexes will be employed if the coefficient of correlation is statistical significance. Data analysis by using Statistical Packages for Social Science (SPSS).

\section{RESULTS AND DISCUSSION}

\section{A. Results}

Data gathered in this study is the scores (interval data) of self-concept questionnaire on the teaching profession (X1), the scores of questionnaires of interest in becoming a teacher (X2), the average score of achievement of prerequisite courses (X3), and the score of microteaching (Y). Therefore, before using parametric statistics Pearson Product Moment, the data should be tested the normality of data distribution. The results are shown Table I.

TABLE I

RESULTS OF TESTS OF NORMALITY

\begin{tabular}{|c|c|c|c|c|c|c|}
\hline \multirow{2}{*}{ Research Variables } & \multicolumn{3}{|c|}{ Kolmogorov-Smirnov $^{a}$} & \multicolumn{3}{|c|}{ Shapiro-Wilk } \\
\hline & Statistic & $\mathrm{df}$ & Sig. & Statistic & $\mathrm{df}$ & Sig. \\
\hline Self-concept (X1) & .11 & 105 & .00 & .94 & 105 & .00 \\
\hline $\begin{array}{l}\text { Interest in } \\
\text { becoming a teacher } \\
(\mathrm{X} 2)\end{array}$ & 11 & 105 & .00 & .96 & 105 & .00 \\
\hline $\begin{array}{l}\text { Prerequisites } \\
\text { courses (X3) }\end{array}$ & .18 & 105 & .00 & .92 & 105 & .00 \\
\hline $\begin{array}{l}\text { Microteaching } \\
\text { competency (Y) }\end{array}$ & .15 & 105 & .00 & .96 & 105 & .00 \\
\hline
\end{tabular}

As shown in Table I, all of the significance values (sig.) are .00 . These statistical values are less than $\alpha=.05(p<.05)$. It concludes that the entire distribution data in this study are unnormal distribution. Therefore, for determining the coefficient of correlations Rank Spearman Rho of nonparametric statistics should be applied.

Bivariate Correlation between Independent Variables $(X)$ and Dependent Variable $(Y)$
By using Rank Spearman Rho, the bivariate coefficient of correlations between predictor variables (X) and dependent variable (Y) individually are as shown in Table II.

TABLE II

Bivariate CoEFFICIENT OF CORRELATIONS ( $\mathrm{N}=105)$

\begin{tabular}{|c|c|c|c|}
\hline Research Variables & $\begin{array}{l}\text { Correlation } \\
\text { Coefficient }\end{array}$ & $\begin{array}{c}\text { Sig. } \\
\text { (2-tailed) }\end{array}$ & Interpretation \\
\hline $\begin{array}{l}\text { Self-concept }(\mathrm{X} 1) \text { and } \\
\text { microteaching } \\
(\mathrm{Y})\end{array}$ & $.35^{* *}$ & .00 & moderate \\
\hline $\begin{array}{l}\text { Interest in becoming a } \\
\text { teacher (X2) and } \\
\text { microteaching competency } \\
\text { (Y) }\end{array}$ & $.38^{* *}$ & .00 & moderate \\
\hline $\begin{array}{l}\text { Prerequisites courses (X3) } \\
\text { and microteaching } \\
\text { competency }(\mathrm{Y})\end{array}$ & $.60^{* *}$ & .00 & sufficient \\
\hline
\end{tabular}

Based on Table II, the results of this study are as follows:

a. There is a positive significant relationship (in moderate category) between self-concept and microteaching competency $\left(r_{s}=.35, \mathrm{p}<.05\right)$. The index determination is $12.25 \%$ indicates the relative contribution of selfconcept variable on prospective teachers' competencies of microteaching is $12.25 \%$ and the remaining $87.75 \%$ is determined by other uninvestigated variables.

b. There is a positive significant relationship (in moderate category) between interest in becoming a teacher and microteaching competency $\left(r_{s}=.38, \mathrm{p}<.05\right)$. The index of determination is $14.29 \%$ indicates the relative contribution of interest in becoming a teacher on prospective teachers' competencies of microteaching is $14.29 \%$ and the remaining $85.71 \%$ is determined by other uninvestigated variables.

c. There is a positive significant relationship (insufficient category) between prerequisites courses and microteaching competency $\left(r_{s}=.60, \mathrm{p}<.05\right)$. The index of determination is $36 \%$ indicates the relative contribution of prerequisites courses variable of this study on prospective teachers' competencies of microteaching is $36 \%$ and the remaining $64 \%$ is determined by other variables.

Multiple Correlation between Dependent Variables (X) and Predictor Variable $(Y)$

The result of the computation of multiple correlations between the independent (predictor) variables (X) and dependent variable $(\mathrm{Y})$ and its significance are shown in Table III and Table IV.

TABLE III

MODEl SUMMARY OF MULTIPLE CORRELATION

\begin{tabular}{|c|c|c|c|c|}
\hline Model & $\mathrm{R}$ & R Square & Adjusted R Square & $\begin{array}{l}\text { Std. Error of the } \\
\text { Estimate }\end{array}$ \\
\hline 1 & $.61^{\mathrm{a}}$ & .38 & .36 & .18 \\
\hline
\end{tabular}


TABLE IV

ANOVA Model Summary for TeSting the SignificanCE of Multiple CORRELATION

\begin{tabular}{|c|c|c|c|c|c|c|}
\hline \multicolumn{2}{|c|}{ Model } & Sum of squares & df & Mean square & $F$ & Sig. \\
\hline \multirow{3}{*}{1} & Regression & 1.95 & 3 & .65 & 20.25 & $.00^{\mathrm{b}}$ \\
\hline & Residual & 3.24 & 101 & .03 & & \\
\hline & Total & 5.19 & 104 & & & \\
\hline
\end{tabular}

a. Dependent Variable: Microteaching competency

b. Predictors: (Constant), Self-concept, Interest in becoming a teacher, Prerequisites courses

Based on Table III and Table IV, it is concluded that there is a positive significant relationship (insufficient category) between self-concept, interest in becoming a teacher, prerequisites courses simultaneously and microteaching competency $(R=0.61, F=20.25, \mathrm{p}<0.05)$. The index of determination is $37.60 \%$ indicates the relative contribution of independent variables on prospective teachers' competencies of microteaching is $37.60 \%$ and the remaining $62.40 \%$ is determined by other uninvestigated variables. The general finding in this study is self-concept, interest in becoming a teacher, prerequisites courses and microteaching competency correlate individually and simultaneously with prospective teachers' competencies of microteaching.

\section{B. Discussion}

\section{Self-Concept and Microteaching}

This study concluded that there was a positive significant relationship (in moderate category) between self-concept factors and the competency of microteaching. This finding is supported by several previous studies that concluded selfconcept in learning positively influences academic achievement and student learning motivation (Efendi, 2013; Fadillah, 2017; Qalsum, Nurhayati, \& Yani, 2015). Dwija (2008) concluded that there was a positive and significant relationship between self-concept and sociology learning outcomes with a contribution of $18.20 \%$. In addition, there is a positive and significant relationship together between selfconcept and interest with learning outcomes with a contribution of $46.30 \%$.

Sistiani (2019) found that family is the main factor as a form of self-concept while the organization (school) is less influential. In relation to microteaching, prospective teachers (students) who carry out exercises in teaching skills in their groups on campus are expected to: (a) be confident and feel equal to others; (b) accepting who we are, recognizing strengths and weaknesses; (c) able to solve problems and be able to evaluate themselves. These factors are the most important part of forming self-concept. In addition, the conception of a student's self relates to or influences his interests and motivation for learning (Bayani, 2012; Sullivan \& Mahalik, 2002).

Remesh et al. (2013) argued that microteaching helps in eliminating errors and builds stronger teaching skills for the beginners and senior teachers increase the self-confidence, improves the in-class teaching performances, and develops the classroom management. Through microteaching training, prospective teachers can strengthen and enhance their self- confidence in mastering teacher professional competencies influences his interests and motivation for learning.

From the research findings as mentioned above, it can be argued that microteaching is a very important tool for training a variety of basic teaching skills as a whole during actual teaching practice. In addition, through microteaching, self-confidence, recognizing and evaluating the advantages and disadvantages of students can be improved. In other words, microteaching is the most important part in the formation of self-concept.

\section{Interest in Becoming a Teacher and Microteaching}

This study concluded that there was a significant positive (in moderate category) relationship that $\mathrm{w}$ between the factors of interest in becoming a science teacher and microteaching. Sistiani (2009) found that: (1) microteaching ability was significantly related to PPL practices; (2) the interest in becoming a teacher is positively related to microteaching abilities and the practice of PPL, and (3) the determination index of microteaching and interest in becoming a teacher towards the practice of PPL is $7.50 \%$. It also found that there was a positive relationship between the interest in being a teacher and learning achievement and asserted that interest in becoming a teacher and family environment correlate significantly with learning achievements (Ningrum, 2013; Widadi, 2000; Widayanti,2005). Setiaji (2015) found that interest in being a teacher was related to teaching career motivation, selfefficacy, and family socioeconomic status. Nesi and Akobiarek (2018) asserted that there was an influence on students' interest in Biology Science learning outcomes in SMAN 2 Jayapura.

Sari, Martono, and Wahyuni (2017) concluded that there was a significant relationship between interest in becoming a teacher and microteaching competency with index of determination $13 \%$. Moreover, there was a significant relationship between interest in becoming a teacher and the grade of field experience program (PPL) with index of determination $24 \%$. The rest is determined by other uninvestigated factors.

Related to the interest, Haussler et al (1998) explained that interest is understood as a trait of the individual, i.e. as the enduring preference for a particular field of knowledge or action (known as individual or personal interest). In addition, interest is interpreted as a state that is related to the specific appeal of a given situation (known as situational interest or interestingness. Furthermore, personal interest (personal interest) is specific to individuals, develops slowly, and tends to have a long-term effect on one's knowledge and values. Whereas situational interest (situational interest) is spontaneous, fleeting, and may only have a short-term effect on individual knowledge and values (Schraw, Flowerday, \& Lehman, 2001). In this context, interest in becoming a teacher can be seen as a personal interest and situational interest.

Lavonen et al. (2005) argue that teachers can seek changes in situational interests for the personal interests of students by selecting content, context, and teaching methods. 
Therefore, it is important for a teacher or lecturer to know the content (content), context, and interests of students. It can be summarized that interest can be seen as an integrated component of psychological, social, and physical factors that are interrelated in a particular learning situation, including in microteaching lectures. To make the teaching and learning materials could be interesting, Schraw, Flowerdwy, and Lehman (2001) suggested that teachers should: (1) offer meaningful choices to pupils (2) use well-organised texts; (3) select texts that are vivid; (4) use texts that pupils know about; (5) encourage pupils to be active learners, and (6) provide relevance cues for pupils.

Kelly (2018) argued that a lack of student interest and motivation can be quite a challenge for teachers to combat. She noted the following methods shown to be effective in getting the students motivated and eager to learn are as follows:

1. Be Warm and Inviting in Your Classroom. The classes have a distinctive personality or "climate" which influences the learning efficiency of their members. No one wants to enter your class where they do not feel welcome. Your classroom should be an inviting place where students feel safe and accepted.

2. Give Choice. Once students have learned a skill or have become familiar with some content, there is always an opportunity to offer a student a choice. Giving students choice is critical to increasing student engagement. In all disciplines, students can be given a choice of questions to answer or a choice between writing prompts and for doing research and problem-solving activities that allow students to have more control over learning to a greater sense of ownership and interest.

3. Authentic Learning. The students are more engaged when they feel that what they are learning is connected to life outside the classroom. The basic idea is that students are more likely to be interested in what they are learning mirrors real-life contexts, equips them with practical and useful skills, and addresses topics that are relevant and applicable to their lives outside of school.

4. Use Project-Based Learning. The process of projectbased learning takes place when students start with a problem to solve, complete research, and then finally solve the problem using tools and information that you would typically teach in a number of lessons.

5. Make Learning Objectives Obvious. Certain topics can be overwhelming because of the amount of information and details involved. Providing students with a road map through accurate learning objectives that shows them exactly what it is you want them to learn can help allay some of these concerns.

6. Make Cross-Curricular Connections. Sometimes students do not see how what they learn in one class intersects with what they are learning in other classes. Cross-curricular connections can provide students with a sense of context while increasing interest in all classes involved. Magnet schools that are based around specific themes like health, engineering, or the arts take advantage of this by having all classes in the curriculum find ways to integrate the students' career interests into their classroom lessons.

7. Show How Students Can Use This Information in the Future. Some students are not interested because they see no point in what they are learning. A common theme among students is, "Why do I need to know this?" Instead of waiting for them to ask this question, why not make it part of the lesson plans that you create. Add a line in your lesson plan template that specifically relates to how students might apply this information in the future. Then make this clear to students as you teach the lesson.

8. Provide Incentives for Learning. Incentives and rewards can be everything from free time at the end of a class. Make it clear to students exactly what they need to do to earn their reward while some people do not like the idea of giving students incentives to learn.

9. Use Hands-On Learning and Include Supporting Materials. Well-designed hands-on activities focus learners on the world around them, spark their curiosity, and guide them through engaging experiences all while achieving the expected learning outcomes. When students are able to feel artefacts or be involved in experiments, the information being taught can acquire more meaning and spark more interest.

Based on some previous findings and theoretical views on interest, it can be asserted that the higher the interest in becoming a teacher, the better the readiness of students to do microteaching exercises and practice field experience. Likewise, on the contrary, the lower the interest in becoming a teacher, the less well-prepared students to do microteaching exercises and practice field experience. It can be concluded that the interest in becoming a teacher can affect microteaching training, and vice versa, microteaching training can influence the interest in becoming a teacher.

\section{Prerequisite Courses and Microteaching}

This study concluded that there is a significant positive relationship (insufficient category) between the prerequisites course and microteaching ability. The relative contribution of the prerequisite courses on the microteaching competency is $36 \%$, and the remaining $64 \%$ is determined by other factors. Prerequisite courses have to take before enrolling microteaching courses in FKIP UNTAN and almost implemented in many LPTK colleges in Indonesia e.g. curriculum analysis, teaching and learning strategies, instructional media, teaching and learning evaluation, and design instructional. Students who take these prerequisite courses must pass a minimum grade of $\mathrm{C}$.

This finding is relevant to the findings of several previous studies. Putri et al. (2014), for instance, concluded that mastery of material was a prerequisite for mathematics learning outcomes. McMillan (2011) concluded that the grade received in prerequisite was positively related to subsequent performance in the organizational behaviour course. In addition, it was also concluded that findings also demonstrate that the common prerequisites may be a rather effective predictor of program performance (Becker, 2014). 
Sato et al (2017) asserted that prerequisite courses are highly faceted of higher education, yet only a handful of studies examine their impact in a scholarly manner.

In microteaching lectures, students are given corrective feedback by supervisors or lectures regarding not only related to their ability to display teaching skills, but also related to mastery and the ability to explain teaching material in a series of ways, make more sense, and easier to understand. The average learning outcomes and mathematical self-efficacy of students given feedback were higher than students who were not given feedback. It is also concluded that giving positive feedback had a positive effect on student learning outcomes. Thus, giving feedback from supervisors is one of the determining factors for the ability and success of students in subsequent microteaching exercises (Ismiyah \& Lestariningsih, 2014).

Compared with the other two independent variables in this investigation, namely self-concept and interest in becoming a science teacher, the prerequisite courses variable showed the highest relative contribution to the ability of microteaching. It can be declared that the prerequisite course is a determinant factor for learning and student learning outcomes.

\section{CONCLUSIONS}

Although self-concept, interest in becoming a teacher, and achievement of prerequisite courses, both individually and simultaneously, relate significantly with the ability of prospective teachers to perform microteaching, however prerequisite courses are the most determinant factors in microteaching regarding preparing a qualified teacher in teacher training institution. The lecturers of microteaching as supervisors should intentionally model the fundamental teaching skills and pedagogy in front of the class during lecturing. Providing corrective feedback to students should be developed as well.

\section{ACKNOWLEDGEMENT}

I would like to thank Dean of FKIP Untan Pontianak for supporting this study through PNBP loans of the academic year 2018. To the prospective teachers who actually administered the questionnaire, I also do thank for their cooperation.

\section{REFERENCES}

Agustina, S., \& Mutia, T. (2015). Hubungan konsep diri, motivasi berprestasi, dengan hasil belajar mahasiswa. Jurnal Education, 10(2), 501-512.

Anggraini, W. (2013). Pengaruh pemberian umpan balik terhadap hasil belajar dan self-efficacy matematis siswa kelas VII SMP. Bachelor Thesis. FKIP Untan, Pontianak. (Unpublished).

Ardi, M. ( 2014). Pelaksanaan pembelajaran microteaching bagi mahasiswa program studi PPKN STKIP-PGRI Pontianak. Jurnal Edukasi, 1(1),75-84.
Asril, Z. (2011). Microteaching disertai dengan pedoman pengalaman lapangan. Jakarta: Raja Grafindo Persada.

Bayani, M. (2012). Hubungan motivasi berprestasi dan konsep diri dengan sikap kreatif (Studi korelasi pada siswa kelas III SD Islam di Kecamatan Pondok Melati Kota Bekasi. Bachelor Thesis. Universitas Negeri Jakarta. (Unpublished).

Becker, L. (2014). Admission criteria for schools of business: Common prerequisites and academic performance in upper-level business coursework. Doctoral Dissertation. University of Central Florida Orlando, Florida. (Unpublished).

Djaali. (2011). Psikologi pedidikan. Jakarta: Bumi Aksara.

Dwija, I. W. (2008). Hubungan antara konsep diri, motivasi berprestasi dan perhatian orang tua dengan hasil belajar sosiologi pada siswa kelas II sekolah menengah atas unggulan di Kota Amlapura. Jurnal Pendidikan dan Pengajaran. 41(1), 98-110.

Efendi, A. (2013). Hubungan antara konsep diri dalam belajar dan motivasi belajar dengan prestasi akademik mahasiswa. Bachelor Thesis. Universitas Lampung. (Unpublished).

Fadilah, S. N. (2017). Pengaruh konsep diri, disiplin belajar dan minat belajar terhadap hasil belajar melalui motivasi belajar ekonomi siswa kelas X SMA Negeri 4 Bandar Lampung. Bachelor Thesis. FKIP Universitas Lampung. (Unpublished).

Frasetyana, A. D. et al. (2015). Analisis keterampilan dasar mengajar mahasiswa pendidikan matematika dalam pembelajaran mikro (studi kasus pada mahasiswa pendidikan matematika FKIP UNS Tahun Akademik 2012/2013). Jurnal Elektronik Pembelajaran Matematika, 3(4),383-394.

Handoyo, T., \& Mulyani, M. S. (1992). Minat mahasiswa IKIP terhadap profesi guru ditinjau dari jenis kelamin, daerah asal, profesi orang tua dalam hubungangya dengan prestasi belajar. Research Report. Yogyakarta: BPPS-UGM.

Haussler, P. (1987). Measuring students' interest in physics-design and results of a cross-sectional study in the Federal Republic of German. International Journal of Science Education,9(1),79-92.

Hidayat, S. (2008). Hubungan minat terhadap profesi guru dan motivasi berprestasi dengan keterampilan mengajar. Jurnal Pendidikan dan Kebudayaan. 75(14), 43-49.

Hurlock, E. (2010). Perkembangan anak.. Transleted by Meitasari Tjandrasa). Jakarta: Penerbit Erlangga.

Ismiyah \& Lestariningsih. (2014). Evaluasi hasil belajar siswa yang diberi umpan balik positif dan negatif pada pokok bahasan Pecahan. Jurnal Pendidikan Matematika STKIP PGRI Sidoarjo. 2(1): 65-74.

Kelly, M. (2017). What to do when students lack interest. Helping students get interested and motivated. Retrieved February 3, 2018, from 
https://www.thoughtco.com/when-students-lackinterest-8086.

Lavonen et al. (2005). Pupil Interest in Physics: A Survey in Finland. Retrieved January 15, 2018, from https://www.educationandemployers.org/.../pupilinterest-in-physics.

Lent, R.W., Brown, S. D., \& Hackett, G. (2000). Contextual support and barriers to career choice: a social cognitive analysis. Journal Counseling Psychology. 47, 36-49.

McMillan, A. (2011). Prerequisite coursework as a predictor of performance in a graduate management course.

https://www.researchgate.net/publication/239529348 [accessed Nov 03 2018].

Mulyasa, E. (2006). Menjadi guru profesional menciptakan pembelajaran kreatif dan menyenangkan. Bandung: Remaja Rosdakarya Offset.

Nesi, M., \& Akobiarek, M. (2018). Pengaruh minat dan penggunaan metode terhadap hasil belajar IPA Biologi siswa kelas VII SMP Negeri 2 Jayapura. Jurnal Pendidikan Biologi dan Sains (Bioedusains), 1 (1), 23-40.

Ningrum, P. K. et al. (2013).Hubungan antara minat menjadi guru dan lingkungan keluarga dengan prestasi belajar.Jurnal Pendidikan Ekonomi UNS. 2(1):59-70.

Putri et al. (2014). Pengaruh penguasaan materi prasyarat terhadap hasil belajar Matematika siswa kelas VIII SMPN 1 Sinjai Timur.Jurnal Matematika dan Pembelajaran (MaPan). 2 (1), 17-29.

Qalsum, U., Nuryahati., \& Yani, A. (2015). Hubungan antara konsep diri dan motivasi berprestasi dengan hasil belajar fisika peserta didik SMA di Kota Makassar. Jurnal Sains dan Pendidikan Fisika,11(2), 132-142.

Remesh et al. (2013). Microteaching as an effective teaching technique. Journal of Research in Medical Science. 18(2), 158-163.

Sari, N., Martono, T., \& Wahyuni, S. (2017). Pengaruh pembelajaran microteaching dan program pengalaman lapangan (PPL) terhadap minat menjadi guru pada mahasiswa, Jurnal Pendidikan Bisnis dan Ekonomi, 2, 3-13.

Sato, B. K. et al. (2017). What's in a Prerequisite? A mixedmethods approach to identifying the impact of a prerequisite course. Journal of CBE Life Science Education, 16(1), 16-30.

Schraw, G., Flowerday, T., \& Lehman, S. (2001). Increasing situational interest in the classroom. Educational Psychology Review, 13(2), 211-224.

Setiaji, K. (2015). Pilihan karir mengajar mahasiswa pendidikan ekonomi (Kajian motivasi karir mengajar, career,self-efficacy, status sosial ekonomi, minat menjadi guru terhadap prestasi akademik). Jurnal Pendidikan Ekonomi Dinamika Pendidikan, 10(2), 196- 211.

Sistiani, D. (2009). Hubungan antara mata kuliah microteaching dan minat menjadi guru terhadap kesiapan mengajar dalam mata kuliah praktik program pengalaman lapangan pada mahasiswa jurusan pendidikan akuntansi. Bachelor Thesis. FKIP Universitas Muhammadiyah Surakarta. (Unpublished).

Slameto. (2010). Belajar dan faktor-faktor yang mempengaruhinya. Jakarta: Rineka Cipta.

Sullivan, K.R., \& Mahalik, R. (2002). Increasing selfefficacy for women: Evaluating a group intervention. Journal of Counseling and Development,78 (2), 5461.

Umura, S.(2015). Profesi guru. http://suhermanaddres.blogspot.co.id/2015/07/profesi -guru.html. Accessed February 3, 2018.

UPT Pembelajaran. (2018). Panduan pelaksanaan micro taeching. Pontianak: FKIP Untan.

Watt, H. M. G., \& Richardson, P. W. (2007). Motivational factors influencing teaching as a career choice: development and validation of the "fit-choice" scale. Journal of Experimental Education, 75 (3), 167-175.

Widadi. (2000). Hubungan antara minat menjadi guru dan motivasi belajar dengan prestasi belajar pada mata kuliah strategi belajar mengajar. Jurnal Paedagogia, 3(1), 27-38.

Widayanti, W. (2005). Pengaruh minat menjadi guru terhadap prestasi belajar mata kuliah Akuntansi pada Prodi Pendidikan Akuntansi Jurusan Ekonomi Universitas Negeri Semarang Angkatan Tahun 2001/2002. Bachelor Thesis. Universitas Negeri Semarang. (Unpublished).

Zlatkovic et al. (2012). Self-concept and teacher's professional roles. Prodia-Social and Behavioral Science, 69, 377-384 